\title{
Enteroparasites and commensals among children in four peripheral districts of Uberlândia, State of Minas Gerais
}

\author{
Enteroparasitas e comensais em crianças de quatro bairros \\ da periferia de Uberlândia, Estado de Minas Gerais
}

Eleuza Rodrigues Machado ${ }^{1}$, Dircelina Silva $\operatorname{Santos}^{1}$ and Julia Maria Costa-Cruz $^{1}$

\begin{abstract}
The aim of this study was to determine the occurrence of intestinal parasites and commensals among children in four peripheral districts located in the northern, southern, eastern and western sectors of Uberlândia, Minas Gerais, using the Baermann methods as modified by Moraes and Lutz. Out of 160 individuals studied, 93 (58.1\% CI: 50.4-65.7) were infected, distributed among the sectors as follows: northern (72.5\%), southern (47.5\%), eastern (57.5\%) and western (55\%). The positive findings according to age groups were: $0-5$ years (26.9\%), 5-10 years (21.2\%) and 10-15 years (10\%). Male children presented 2.7 times higher risk of infection than females did (OR: 2.7; CI: 1052-7001). The parasites and commensals identified were: Giardia lamblia (27.5\%), Entamoeba coli (20.6\%), Ascaris lumbricoides (14.4\%), Enterobius vermicularis (8.8\%), Hymenolepis nana (7.5\%), Hymenolepis diminuta (5\%), hookworms (3.1\%), Trichuris trichiura (2.5\%), Endolimax nana (2.5\%), Entamoeba hartmanni (2.5\%), Strongyloides stercoralis (1.3\%), Iodamoeba butschlii (1.3\%) and Capillaria hepatica (0.6\%). The infection rate in these children was high and showed the need to implement prophylactic education programs in the community.
\end{abstract}

Key-words: Enteroparasites. Commensals. Children. Epidemiology. Brazil.

\section{RESUMO}

O objetivo deste estudo foi determinar a ocorrência de parasitas e comensais intestinais em crianças de quatro bairros periféricos, localizados nos setores norte, sul, leste e oeste em Uberlândia, Minas Gerais, utilizando os métodos de Baermann modificado por Moraes, e de Lutz. Dos 160 indivíduos estudados, 93 (58,1\%, IC: 50,4-65,7) estavam infectados, assim distribuídos: setor norte (72,5\%), sul (47,5\%), leste (57,5\%) e oeste (55\%). A positividade por faixa etária foi: 0 - 5 anos (26,9\%), 5 - 10 (21,2\%) e 10 - 15 anos (10\%). As crianças do sexo masculino mostraram 2,7 maior risco de infecção (OR: 2,7, IC: 1052-7001). Os agentes identificados foram: Giardia lamblia (27,5\%), Entamoeba coli (20,6\%), Ascaris lumbricoides (14,4\%), Enterobius vermicularis (8,8\%), Hymenolepis nana (7,5\%), Hymenolepis diminuta (5\%), ancilostomídeos (3,1\%), Trichuris trichiura (2,5\%), Endolimax nana (2,5\%), Entamoeba hartmanni (2,5\%), Strongyloides stercoralis (1,3\%), Iodamoeba butschlii $(1,3 \%)$ e Capillaria hepatica $(0,6 \%)$. A porcentagem de infecção nas crianças foi alta e mostrou a necessidade de implantação de programas de educação profilática na comunidade.

Palavras-chaves: Enteroparasitas. Comensais. Crianças. Epidemiologia. Brasil.

It has been estimated that infections caused by intestinal protozoa and helminths affect 3.5 billion people around the world and cause disease in approximately 450 million people, most of whom children ${ }^{27}$. Intestinal parasitic infections are public health problems, especially due to symptoms such as diarrhea, anemia, other gastrointestinal dysfunctions and behavioral effects $^{57121318}$

Children are an important high-risk group for helminth infections because they are: 1) in a period of intense physical growth and rapid metabolism, resulting in increased nutritional needs; when these needs are not adequately met, individuals are more susceptible to infection; 2) in a period of intense learning; helminth infections have been shown to have a negative impact on cognitive tasks; and 3) continuously exposed to contaminated soil and water but probably lacking in awareness of the need for good personal hygiene ${ }^{18}$.

The objective of the present study was to determine the occurrence of enteroparasites and commensals among children in four peripheral districts of the City of Uberlândia, State of Minas Gerais, Brazil, between October 1996 and June 1997.

1. Departamento de Imunologia, Microbiologia e Parasitologia, Instituto de Ciências Biomédicas, Universidade Federal de Uberlândia, Uberlândia, MG. Address to: Dra. Eleuza Rodrigues Machado. Depto. de Imunologia, Microbiologia e Parasitologia /ICBIM/ UFU. Av. Pará 1720, 38400-902 Uberlândia, MG. Tel.: +55 34 3218-2198; Fax: + $55343218-2332$.

e-mail: ermachad@hotmail.com/eleuzamachado@gmail.com

Recebido para publicação em 16/04/2008

Aceito em 13/10/2008 


\section{MATERIAL AND METHODS}

There are 241 districts registered with the municipal authorities of the City of Uberlândia, Triângulo Mineiro region. These districts are divided into sectors: central, northern, southern, eastern and western, in accordance with data from the Transport and Transit Department. One peripheral district from each sector was selected at random: Esperança (northernern), São Jorge (south), Dom Almir (eastern) and Tocantins (western).

The sample size was calculated ${ }^{24}$ according to the formula: $\mathrm{n}=\mathrm{Z}^{2} \times \mathrm{P} \mathrm{Q} / \mathrm{d}^{2}$, in which $(\mathrm{Z})$ was $95 \%$, (d) was $5 \%$ and $(\mathrm{P})$ was $88.4 \%$ (obtained from a study on intestinal parasites in the City of Uberlândia), and a non-observed value (Q) of $11.6 \%$, and thus the sample size (n) was taken to be 159 people. These individuals were randomly selected. The number was increased to 160 , such that 40 individuals from each district were analyzed.

Fecal samples were collected after making home visits at which the children were identified by sex and age ( $0-15$ years), and consent was given by their parents or relatives for their participation. Three fecal samples from each person were collected in plastic vials without preservatives at intervals of four to six days. The samples were stored in polystyrene boxes and analyzed at the Parasitology Laboratory of the Federal University of Uberlândia, by means of the Baermann methods, as modified by Moraes ${ }^{19}$ and Lutz ${ }^{15}$. Six slides were prepared, stained with Lugol's iodine ${ }^{8}$ and each sample was read by two investigators. The total number of slides examined was thus 3,840, such that 2,880 were examined using the BaermannMoraes method and 960 using the Lutz method. All these individuals received their diagnostic results, and the positive cases were referred to the hospital, where they received specific treatment.

The results from the parasitological examinations were analyzed using the chi-square test $\left(\mathrm{X}^{2}\right)$ and odds ratio with $95 \%$ confidence interval (CI) (Instat software).

\section{RESULTS}

Out of the 160 children, 93 (58.1\%; CI: 50.4-65.7) were positive for enteroparasites or commensals, distributed between the sectors as follows: northern (72.5\%), southern (47.5\%), eastern (57.5\%) and western (55\%). Table 1 shows the frequencies of enteroparasites and commensals detected in the children according to age and district. The rates of positive findings in relation to age groups were: $0-5$ years (46.2\%), 5-10 years (36.5\%) and $10-15$ years (17.2\%). Out of the total number of children infected, $49(52.7 \%)$ were male and 44 (47.3\%) were female. The frequency of children infected according to sex in the four districts was: northern, 19 (47.5\%) males and 10 (25\%) females; southern, 8 (20\%) males and 11 (27.5\%) females; eastern, 9 (22.5\%) males and 14 (35\%) females; and western, $13(32.5 \%)$ males and 9 (22.5\%) females. There was a significant difference in the number of positive cases according to sex only among the children living in the northern sector $(P<0.05)$. Male children presented 2.7 times higher risk of infection than female children did (OR: 2.7; CI: 1,052 to 7,001).

The distribution of intestinal parasites and commensals diagnosed is shown in Table 2. All the enteroparasites and commensals were demonstrated in all four sectors analyzed, but without statistical differences between the sectors.

There were 55 (59.1\%) cases of monoparasitism, 21 (22.6\%) cases of biparasitism, and 17 (18.3\%) cases of polyparasitism. Table 3 shows the 38 associations among the children infected with intestinal parasites and commensals. Among these 38 associations observed, 20 bi-associations and 18 poly-associations involving Giardia lamblia were present and a high prevalence of this protozoan was confirmed in 11 cases of bi-associations and 9 cases of poly-associations. Ascaris lumbricoides appeared in 9 bi-associations and 8 poly-associations. Capillaria bepatica was associated with Giardia lamblia. Entamoeba coli was present in 11 bi-associations and 11 poly-associations.

Table 1 - Frequencies of enteroparasites and commensals detected in children according to age and peripheral districts in the City of Uberlândia, State of Minas Gerais, Brazil, between October 1996 and June 1997.

\begin{tabular}{|c|c|c|c|c|}
\hline $\begin{array}{l}\text { Districts/ } \\
\text { Age } \\
\text { (years) }\end{array}$ & $\begin{array}{l}\text { Samples } \\
\text { (per district) } \\
\left(\mathrm{n}^{0}=40\right)\end{array}$ & $\begin{array}{c}\text { Positive } \\
\text { cases according } \\
\text { to age (\%) }\end{array}$ & $\begin{array}{l}\text { Positive findings } \\
\text { per district } \\
\left(\mathrm{n}^{\mathrm{0}}=40\right)\end{array}$ & $\begin{array}{c}\text { Total } \\
\text { positive } \\
(\%)\end{array}$ \\
\hline \multicolumn{5}{|l|}{ Northern } \\
\hline $0 \neg 5$ & 23 & 16 & 69.6 & 40.0 \\
\hline $5 \neg 10$ & 14 & 10 & 71.4 & 25.0 \\
\hline $10 \neg 15$ & 3 & 3 & 100.0 & 7.5 \\
\hline \multicolumn{5}{|l|}{ Southern } \\
\hline $0 \neg 5$ & 14 & 8 & 57.1 & 20.0 \\
\hline $5 \neg 10$ & 17 & 7 & 41.2 & 17.5 \\
\hline $10 \neg 15$ & 9 & 4 & 44.4 & 10.0 \\
\hline \multicolumn{5}{|l|}{ Eastern } \\
\hline $0 \neg 5$ & 15 & 11 & 73.3 & 27.5 \\
\hline $5 \neg 10$ & 19 & 10 & 52.6 & 25.0 \\
\hline $10 \neg 15$ & 6 & 2 & 33.3 & 5.0 \\
\hline \multicolumn{5}{|l|}{ Western } \\
\hline $0 \neg 5$ & 5 & 8 & 53.3 & 20.0 \\
\hline $5 \neg 10$ & 14 & 7 & 50.0 & 17.5 \\
\hline $10 \neg 15$ & 11 & 7 & 63.6 & 17.5 \\
\hline
\end{tabular}

Table 2 - Frequencies of enteroparasites and commensals detected among 160 children living in peripheral districts of the City of Uberlândia, State of Minas Gerais, Brazil, between October 1996 and June 1997.

\begin{tabular}{lcc}
\hline & \multicolumn{2}{c}{ Positive findings } \\
\cline { 2 - 3 } Intestinal parasites and commensals & Number & Percentage \\
\hline Giardia lamblia & 44 & 27.6 \\
Entamoeba coli & 33 & 20.7 \\
Ascaris lumbricoides & 23 & 14.4 \\
Enterobius vermicularis & 14 & 8.8 \\
Hymenolepis nana & 12 & 7.5 \\
Hymenolepis diminuta & 8 & 5.0 \\
Hookworms & 5 & 3.1 \\
Trichuris trichiura & 4 & 2.5 \\
Endolimax nana & 4 & 2.5 \\
Entamoeba hartmanni & 4 & 2.5 \\
Iodamoeba butschlii & 2 & 1.3 \\
Strongyloides stercoralis & 2 & 1.3 \\
Capillaria hepatica & 1 & 0.6 \\
\hline
\end{tabular}


Table 3 - Distribution of associations among enteroparasites and commensals detected in children living in peripheral districts of the City of Uberlândia, State of Minas Gerais, Brazil, between October 1996 and June 1997.

\begin{tabular}{|c|c|c|}
\hline Associations & Number & Percentage \\
\hline Giardia lamblia + Ascaris lumbricoides & 4 & 10.5 \\
\hline Giardia lamblia + Entamoeba coli & 3 & 7.9 \\
\hline Giardia lamblia + Enterobius vermicularis & 1 & 2.6 \\
\hline Giardia lamblia + Capillaria bepatica & 1 & 2.6 \\
\hline Giardia lamblia + Hymenolepis nana & 1 & 2.6 \\
\hline Giardia lamblia + Endolimax nana & 1 & 2.6 \\
\hline Hymenolepis nana + Entamoeba coli & 1 & 2.6 \\
\hline Hymenolepis nana + Hymenolepis diminuta & 1 & 2.6 \\
\hline Ascaris lumbricoides + Entamoeba coli & 4 & 10.5 \\
\hline Enterobius vermicularis + Entamoeba coli & 2 & 5.3 \\
\hline Ascaris lumbricoides + Hookworms & 1 & 2.6 \\
\hline Entamoeba coli + Entamoeba hartmanni & 1 & 2.6 \\
\hline Giardia lamblia + Hymenolepis nana + Hymenolepis diminuta & 2 & 5.3 \\
\hline Giardia lamblia + Hymenolepis nana + Entamoeba coli & 2 & 5.3 \\
\hline Giardia lamblia + Entamoeba coli + Endolimax nana & 1 & 2.6 \\
\hline Giardia lamblia + Ascaris lumbricoides + Trichuris trichiura & 1 & 2.6 \\
\hline Giardia lamblia + Entamoeba coli + Iodamoeba butschlii & 1 & 2.6 \\
\hline Ascaris lumbricoides + Enterobius vermicularis + Entamoeba coli & 2 & 5.3 \\
\hline Ascaris lumbricoides + Hymenolepis nana + Hymenolepis diminuta & 1 & 2.6 \\
\hline Enterobius vermicularis + Entamoeba coli + Endolimax nana & 1 & 2.6 \\
\hline Enterobius vermicularis + Hymenolepis nana + Hymenolepis diminuta & 1 & 2.6 \\
\hline Giardia lamblia + Ascaris lumbricoides + Enterobius vermicularis + Entamoeba coli & 1 & 2.6 \\
\hline Ascaris lumbricoides + Trichuris trichiura + Hookworms + Entamoeba coli & 1 & 2.6 \\
\hline Giardia lamblia + Ascaris lumbricoides + Trichuris trichiura + Hymenolepis diminuta + Entamoeba coli & 1 & 2.6 \\
\hline Ascaris lumbricoides + Hookworms + Hymenolepis nana + Hymenolepis diminuta + Entamoeba coli & 1 & 2.6 \\
\hline Total & 38 & 100.0 \\
\hline
\end{tabular}

\section{DISCUSSION}

The percentages of positive findings of intestinal parasites and/or commensals detected in this study reflected the high exposure of this community to contaminated soil and precarious hygiene habits. In other studies on Brazilian children, the rate of findings of intestinal parasites and commensals ranged between $24.6 \%{ }^{17}$ and $92 \%{ }^{11}$, although the infection percentages recorded in the literature on children in Uberlândia have been between $28.3 \%{ }^{28}$ and $88.4 \%{ }^{16}$.

The results found in this study showed that the basic sanitation conditions and hygiene habits of individuals from the peripheral sectors of this city are still poor, thus resulting in high rates of infection and confirming the data described in the literature ${ }^{16}$.

In the present study, the occurrence of infections was greatest among children aged zero to five years. Data demonstrated by our group have revealed that the age category most susceptive to parasitic infection is from zero to 15 years. Nevertheless, whatever the age of the children, the possibility that they might put objects or hands infected with eggs and/or cysts into their mouths arises because of poor hygiene habits ${ }^{16}$. In the present study, the number of positive cases found among these children was higher among the boys than among the girls. Similar results according to sex were described by Machado and Costa-Cruz ${ }^{16}$, with infection occurrence higher among boys. We believe that this difference in the rate of parasitism according to sex may be due to greater contact by boys with infected material while they are playing.

Giardia lamblia was the only pathogenic protozoa diagnosed with high frequency. This result was similar to what has been described in the literature ${ }^{4610}$. However, our data showed lower rates than did the results from other studies conducted on this protozoan in the same city ${ }^{16}$.

The amoebae found in the gastrointestinal tract (Entamoeba coli, Entamoeba hartmanni, Endolimax nana and Iodamoeba butschlii) are commensal protozoa. In several countries, many people are infected by these commensals, but all of them are asymptomatic. Our results, as well as data on commensals recorded in the literature ${ }^{1420}$, have demonstrated high infection rates. These results indicate that children have ingested things containing fecal residues. This confirms the importance of diagnostics and descriptions for these commensals, in order to obtain preventive measures aimed at avoiding waterborne and foodborne infections due to fecal contamination. The form of contamination for these commensals is the same as for other pathogenic parasites.

Ascaris lumbricoides was the helminth with the highest occurrence rate. This result confirmed data reported by other authors, who described a high frequency of this helminth in Brazil ${ }^{916}$. 
The frequency observed for Trichuris trichiura was lower in this study, but similar results have been described ${ }^{1617}$.

Although the diagnostic methods used were not specific for Enterobius vermicularis, a high frequency was found. However, this result was lower than in data in the literature obtained using a specific method ${ }^{28}$. The frequencies of Hymenolepis nana and Hymenolepis diminuta found in the present study were similar to the data in the literature ${ }^{1628}$.

Low numbers of positive cases of hookworms and Strongyloides stercoralis were found in the present study. We believe that the small percentage of infections with these two nematodes was due to their similar form of infection, which is by means of active penetration of infective larvae into the skin and mucosal membrane when people handle soil or ingest contaminated food or water. For hookworms, the positive percentage has ranged from $2.6 \%{ }^{22}$ to $17.9 \%^{2}$. Therefore, the results found in the present study are similar to the mean shown in the national literature ${ }^{21622}$. The prevalence of Strongyloides stercoralis in the present study was similar to other results that have been demonstrated ${ }^{1722}$. Furthermore, an infection rate for strongyloidiasis of $13 \%$ has been demonstrated $^{16}$, thus characterizing this region as hyperendemic for this parasite. We suggest that the different results in the literature may be due to the ages of the children studied ${ }^{16}$, who were between zero and seven years old. In contrast, in the present study, the children were between zero and 15 years; and older children have better hygiene habits and lower rates of infection.

Capillaria species are parasites in many vertebrate animals but only three species infect humans: Capillaria hepatica, Capillaria aerophila and Capillaria philippinensis, which cause hepatic, pulmonary and intestinal capillariasis, respectively ${ }^{25}$. Capillaria bepatica produces zoonotic infection of rather common occurrence among rats and mice but which is extremely rare in humans. No more than 30 cases have been reported worldwide ${ }^{21}$. There has only been one report from Brazil so far, concerning three cases of children with massive hepatic capillariasis that was diagnosed by means of hepatic biopsy. These cases presented the characteristic trio of the true infection, i.e. persistent fever, hepatomegaly, and eosinophilia ${ }^{26}$. Human hepatic capillariasis, caused by the ingestion of embryonated eggs, may vary from mild to severe in intensity, and sometimes it can be fatal. Some of the more common signs and symptoms include the classical trio described above, plus splenomegaly, pneumonitis, fever, extreme weakness, constipation, abdominal distension and, sometimes, ascites and malnutrition ${ }^{26}$. No eggs appear in the host feces except in cases of spurious Capillaria hepatica infection acquired by ingestion of non-infective immature eggs ${ }^{1}$. In the present study, Capillaria hepatica eggs were found in feces of an asymptomatic child of 19 months of age, thus suggesting a spurious infection ${ }^{1}$ or ingestion of insufficiently cooked liver from a parasitized animal ${ }^{23}$. In both cases, the eggs pass through the digestive tract without been hatched and could be detected in the fecal samples.

There was predominance of monoassociation, followed by bi-association and poly-association. These results confirm the data shown in the literature ${ }^{3916}$. The diagnoses and descriptions of these associations are important for the specific treatment of each parasite.
In conclusion, the high rate of enteroparasites and commensals seen among children represents a serious public health problem and suggests that there is a need for prophylactic education programs in the community, with the aim of controlling the risk factors for enteroparasites.

\section{ACKNOWLEDGMENTS}

This study was supported by grants from the Coordination Office for the Biological Sciences Course of the Federal University of Uberlândia, State of Minas Gerais, Brazil. We are grateful to Maria das Graças Marçal for help with the parasitological techniques.

\section{REFERENCES}

1. Andrade ZA, Assis BCA, Souza MM. Capillaria hepatica: papel em patologia humana e potencial como modelo experimental. In: Coura JR (ed) Dinâmica das doenças infecciosas e parasitárias. Editora Guanabara Koogan, Rio de Janeiro, p.1121-1132, 2005

2. Berbert-Ferreira M, Costa-Cruz JM. Parasitas intestinais em lactentes de 4 a 12 meses, usuários das creches da Universidade Federal de Uberlândia, Minas Gerais. Jornal de Pediatria 71: 219-222 1995.

3. Cardoso GS, Santana ADCI, Aguiar CP. Prevalência e aspectos epidemiológicos da giardiasis em creches no município de Aracaju, SE, Brasil. Revista da Sociedade Brasileira de Medicina Tropical 28: 25-31, 1995

4. Carvalho TB, Carvalho LR, Mascarini LM. Occurrence of enteroparasites in day care centers in Botucatu (São Paulo State, Brazil) with emphasis on Cryptosporidium sp., Giardia duodenalis and Enterobius vermicularis. Revista do Instituto de Medicina Tropical de São Paulo 48: 269-273, 2006.

5. Chieffi PP, Waldman EA, Waldman CC, Sakata EE, Gerbi LJ, Rocha AB, Aguiar PR. Epidemiological aspects of enteroparasitosis in the State of Sao Paulo, Brazil. Revista Paulista de Medicina 99: 34-36, 1982.

6. Costa-Macedo LM, Machado-Silva JR, Rodrigues-Silva R, Oliveira LM, Vianna MS Intestinal parasitoses in preschool children of the slum communities of the city of Rio de Janeiro, Brazil. Cadernos de Saúde Pública 14:851-855, 1998.

7. Coulter JBS. Global importance of parasitic disease. Current Paediatrics 12: 523-533, 2002.

8. De Carli GA. Parasitologia clínica. Seleção de métodos e técnicas de laboratório para o diagnóstico das parasitoses humanas. Editora Atheneu, São Paulo, p.3839, 2001.

9. Dórea RCC, Salata E, Padovani CR, Anjos GL. Control of parasitic infections among school children in the peri-urban area of Botucatu, São Paulo, Brazil. Revista da Sociedade Brasileira de Medicina Tropical 29: 425-430, 1996.

10. Ferreira GR, Andrade CF. Some socioeconomic aspects related to intestinal parasitosis and evaluation of an educational intervention in scholars from Estiva Gerbi, SP. Revista da Sociedade Brasileira de Medicina Tropical 38: 402-405, 2005.

11. Fontes G, Oliveira KK, Oliveira AK, Rocha EM. Influence of specific treatment of intestinal parasites and schistosomiasis on prevalence in students in Barra de Santo Antonio, AL. Revista da Sociedade Brasileira de Medicina Tropical 36: 625-628, 2003.

12. Jardim-Botelho A, Brooker S, Geiger SM, Fleming F, Lopes ACS, Diemert DJ, Corrêa-Oliveira R, Bethony JM. Age patterns in undernutrition and helminth infection in a rural area of Brazil: associations with ascariasis and hookworm. Tropical Medicine International Health 13: 458-467, 2008.

13. Jasti A, Ojha SC, Singh YI. Mental and behavioral effects of parasitic infections: a review. Nepal Medical College Journal 9: 50-56, 2007.

14. Kobayashi J, Hasegawa H, Forli AA, Nishimura NF, Yamanaka A, Shimabukuro T, Sato Y. Prevalence of intestinal parasitic infection in five farms in Holambra, 
São Paulo, Brazil. Revista do Instituto de Medicina Tropical de São Paulo 37: 13-18, 1995

15. Lutz AV. Schistosoma mansoni e a schistosomose, segundo observações feitas no Brasil. Memórias do Instituto Oswaldo Cruz 11: 121-125 1919.

16. Machado ER, Costa-Cruz JM. Strongyloides stercoralis and other enteroparasites in children at Uberlândia city, state of Minas Gerais, Brazil. Memórias do Instituto Oswaldo Cruz 93: 161-164, 1998.

17. Menezes AI, Lima VMP, Freitas MTS, Rocha MO, Silva EF, Dolabella SS. Prevalence of intestinal parasites in children from public daycare centers in the city of Belo Horizonte, Minas Gerais, Brazil. Revista do Instituto de Medicina Tropical de São Paulo 50: 57-59, 2008.

18. Montresor A, Crompton DWT, Gyorkos TW, Savioli L. Helminth control in school-age children: a guide for managers of control programmes. World Health Organization, Geneva, 2002.

19. Moraes RG. Contribuição para o estudo do Strongyloides stercoralis e da estrongiloidíase no Brasil. Revista do Serviço Especial de Saúde Pública 1: $507-624,1948$

20. Nascimento SA, Moitinho ML. Blastocystis hominis and other intestinal parasites in a community of Pitanga City, Paraná State, Brazil. Revista do Instituto de Medicina Tropical de São Paulo 47: 213-217, 2005.
21. Pampiglione $S$, Gustinelli A. Human hepatic capillariasis: a second case occurred in Korea. Journal of Korean Medical Science 23: 560-561, 2008.

22. Paula FM, Castro E, Gonçalves-Pires M, Marçal MO, Campos DMB, Costa-Cruz JM. Parasitological and immunological diagnoses of strongyloidiasis in immunocompromised and non-immunocompromised children at Uberlândia State of Minas Gerais, Brazil. Revista do Instituto de Medicina Tropical de São Paulo 42: 51-55, 2000.

23. Rey L. Parasitologia. $3^{\text {a }}$ edição. Guanabara Koogan, Rio de Janeiro, RJ, 2001.

24. Rodrigues PC. Bioestatística. Editora Universitária, Niterói, RJ, 1986.

25. Saichua P, Nithikathkul C, Kaewpitoon N. Human intestinal capillariasis in Thailand. World Journal of Gastroenterology 14:506-510, 2008.

26. Sawamura R, Fernandes MI, Peres LC, Galvão LC, Goldani HA, Jorge SM, Rocha GM, Souza NM. Hepatic capillariasis in children: report of 3 cases in Brazil. The American Journal of Tropical Medicine and Hygiene 61: 642-647, 1999.

27. Schuster H, Chiodini PL. Parasitic infections of intestine. Current Opinion Infection Disease 14: 587-591, 2001.

28. Silva JJ, Borges R, Silveira AC, Silva LP, Mendes J. Enterobiasis and other intestinal parasitoses in children attending educational institutions in Uberlândia, state of Minas Gerais, Brazil. Revista de Patologia Tropical 32: 87- 94, 2003. 